\title{
Effects of rhizodeposition of non-transgenic and transplastomic tobaccos on the soil bacterial community
}

\author{
Lorenzo BRUSETTI ${ }^{1 *}$, Aurora RIZZI ${ }^{*}$, Alessandro ABRUZZESE², Gian Attilio SACCHI ${ }^{2}$, Enzio RAGG ${ }^{3}$, \\ Marco BAZZICALUPO ${ }^{4}$, Claudia SORLINI ${ }^{4}$ and Daniele DAFFONCHIO ${ }^{1, \star \star}$ \\ 1 Dipartimento di Scienze e Tecnologie Alimentari e Microbiologiche (DISTAM), Università degli Studi di Milano, via Celoria 2, \\ 20133, Milano, Italy \\ 2 Dipartimento di Produzione Vegetale (DIPROVE), Università degli Studi di Milano, via Celoria 2, 20133, Milano, Italy \\ 3 Dipartimento di Scienze Molecolari ed Agroalimentari (DISMA), Università degli Studi di Milano, via Celoria 2, 20133, Milano, Italy \\ ${ }^{4}$ Dipartimento di Biologia Animale e Genetica (DBAG), Università degli Studi di Firenze, via Romana 17, 50125, Firenze, Italy
}

The effect of root-released compounds of transplastomic tobacco (Nicotiana tabacum) on the soil bacterial community structure, and their potential to support horizontal gene transfer (HGT) to bacteria have been studied. Soil microcosms were exposed to root-released compounds collected from transplastomic and non-transgenic tobacco cultivars. Cluster analysis of automated ribosomal intergenic spacer analysis (ARISA) profiles of the soil bacterial community after $48 \mathrm{~h}$ incubation grouped the transgenic cultivar apart from the non-transgenic, indicating that it had a rhizodeposition pattern different from the parental plants. However, these differences were less than between the two non-transgenic tobacco cultivars studied. NMR characterization of the rootreleased compounds showed some differences in chemical fingerprinting pattern between the transplastomic and the parental cultivar. However, the effect on bacterial community structure was transient, and tended to disappear after $96 \mathrm{~h}$ of incubation. The potential of root-released compounds as a source of transforming DNA for bacteria was investigated by using four potential recipient species. No transformants were obtained following exposure of all the recipients to the root-released compounds. Root-released compounds amended to transgene donor DNA decreased the transformation frequency of Acinetobacter baylyi strain ADP1200, while Azospirillum, Agrobacterium, and Sinorhizobium strains failed to develop competence also in the presence of an external added transgene source. Detection of plastid sequences by PCR suggested that a very low amount of fragmented plastid donor DNA was present in the root-released compounds.

Keywords: transplastomic tobacco / root-released compounds / soil bacterial diversity / horizontal gene transfer / Acinetobacter / root exudate composition

\section{INTRODUCTION}

Root-associated bacteria are very sensitive to small changes in the pattern of organic compounds in the rhizosphere (Hinsinger et al., 2005; Kent and Triplett, 2002; Pal et al., 2001; Persello-Cartieaux et al., 2003), to the point that even different plant cultivars of the same species can select different bacterial communities (Chiarini et al., 1998; Gomes et al., 2001; Milling et al., 2004). Several studies showed differences in the bacterial community structure between genetically modified plants (GMPs) and the parental non-transgenic cultivars (Di Giovanni et al., 1999; Gyamfi et al., 2002), but few focused on the effect of root-released compounds.

\footnotetext{
* These two authors contributed equally to the work.

** Corresponding author: daniele.daffonchio@unimi.it
}

Brusetti et al. (2004) showed that soil exposed to root-released compounds of transgenic Bt-maize and its parental non-transgenic counterpart selected different bacterial communities.

A multitude of compounds are released into the rhizosphere by roots as a consequence of exudation or rhizodeposition. Root-released compounds also include high molecular weight molecules such as proteins, enzymes, polysaccharides and DNA. The DNA released from the roots, due to apical cell lysis, may serve as transforming DNA of naturally competent rhizosphere bacteria. This process could be enhanced in the case of transplastomic plants that harbor up to 1000 times more transgene copies per plant cell than nuclear GMPs (Daniell et al., 1998). Indeed it has been shown that transformation frequency of Acinetobacter sp. BD413 (now Acinetobacter baylyi (Vaneechoutte et al., 2006)) is 


\section{Brusetti et al.}

higher when the cells are exposed to transplastomic than to nuclear GMP plant DNA (Kay et al., 2002). Moreover, the plant DNA released in the rhizosphere can be protected against degradation by adsorption to soil colloids and possibly be available to horizontal gene transfer (HGT) up to 77-137 days after its release (Gallori et al., 1994; Khanna and Stotzky, 1992; Paget et al., 1992; Pietramellara et al., 1997; Widmer et al., 1997).

Here we present the results of a study aiming to assess the effect of root-released compounds from transplastomic tobacco on the soil bacterial community. We analyzed the structure of the soil bacterial community following exposure to the root-released compounds of the transplastomic tobacco PBD6t, and non-transgenic tobacco cultivars. Transplastomic tobacco PBD6t harbors in its plastid genome a copy of an aadA gene, conferring resistance to both spectinomycin and streptomycin (Kay et al., 2002). We also investigated root-released compounds as potential source of transforming DNA for soil and rhizosphere recipient strains. In addition, the possible presence of transforming DNA in the root-released compounds was evaluated by PCR.

\section{RESULTS}

\section{Effect of root-released compounds on the structure of the soil bacterial community}

The effect of the root-released compounds of a transplastomic tobacco (PBD6t) on the soil bacterial community structure was studied along with that of the parental non-transgenic cultivar (PBD6) and a second non-transgenic cultivar (Perustitza). Further information about tobacco cultivars are given in the Materials and Methods section.

The compounds released into bidistilled water, after a treatment with an antimicrobial agent, from roots of 18 hydroponically grown tobacco plants were collected daily and pooled. The root-released compounds were concentrated by lyophilization, resuspended in water, and added to the soil microcosms. A total of $425 \mu \mathrm{g} . \mathrm{mL}^{-1}$ organic carbon was added to each of the soil microcosms, containing $0.12 \mathrm{~g}$ of organic carbon per gram of soil. After 48 and $96 \mathrm{~h}$ of incubation, the total DNAs extracted from soil samples were analyzed by Automated Ribosomal Intergenic Spacer Analysis (ARISA) (Fig. 1 and Tab. 1). The number of peaks in the ARISA profiles ranged between 59 and 84, and between 50 and 90 for soil samples incubated for 48 and $96 \mathrm{~h}$, respectively. The fragment length was between 152 and $738 \mathrm{bp}$, and between 152 and $904 \mathrm{bp}$, respectively. The normalized average peak height was 132 and 140 fluorescent units after 48 and $96 \mathrm{~h}$, respectively, with a percentage of peaks higher than the average height of $32.7 \%$ and $31.6 \%$, respectively.

Comparison of ARISA electropherograms showed that all soil microcosms treated with solutions containing root-released compounds gave highly similar profiles irrespective of the diverse source of compounds. The control soil microcosms amended with water gave a different profile from all the other microcosms in the region between 200 and $500 \mathrm{bp}$, after both 48 and $96 \mathrm{~h}$ of incubation. In this region of the electropherograms, the peak height was constantly lower than in the microcosms amended with tobacco root-released compounds (Tab. 1 and Fig. 1). Differences in terms of presence/absence of peaks between cultivars were limited. For example, only PBD6t and PBD6 microcosms at $48 \mathrm{~h}$ shared the high peak at $236 \mathrm{bp}$, as well as a small peak at $491 \mathrm{bp}$, at both 48 and $96 \mathrm{~h}$. The inter-cultivar similarity was relatively high, comprised between 60 and $70 \%$ of the peaks, as confirmed by replicated microcosms (Fig. 1 and Tab. 1). At $48 \mathrm{~h}$, considering only peaks conserved among all five replicate microcosms, the transgenic tobacco, PBD6t, with respect to the parental non-transgenic cultivar PBD6, had a high peak at $661 \mathrm{bp}$, lacked peaks at $229,238,247,535 \mathrm{bp}$, and a number of relatively high peaks in the region between 290 and 310 bp (Fig. 1).

Seven diversity indices were calculated from the ARISA profiles to better address the ecological description of the bacterial community within samples (Magurran, 1988; Tab. 1). Species richness, coinciding with the number of peaks, was between 60.8 and 78.0. Diversity indices like Shannon-Weaver, Simpson, Menhinick and Margalef were in general high. For example, the Simpson index, indicating the strength of the dominant species in the community, was between 0.97 and 0.98 , nearly the maximum value of 1 , while the Dominance index was very low, between 0.2 and 0.3 . Although a single bacterial species can produce more than one peak, peak number in ARISA profiles has been used as an indicator of bacterial diversity in a complex community (Fisher and Triplett, 1999). By adopting the same assumption, the present ARISA data indicate that the soil bacterial community, independently from root-released compound amendment, was characterized by a high bacterial diversity and species richness. The Equitability index, indicating the maximum relative bacterial diversity in an environmental sample, was always close to 1 (range 0.89 to 0.96 ). The analysis of variance showed that the soil bacterial community exposed to the root-released compounds of transplastomic PBD6t tobacco for $48 \mathrm{~h}$ significantly differed from that exposed to root-released compounds of parental PBD6 tobacco in Dominance and Simpson indices $(P<0.002)$. At $48 \mathrm{~h}$, the transplastomic cultivar (T) samples differed from some $48 \mathrm{~h}$ samples of the non-transgenic cultivars $(\mathrm{P}$ and $\mathrm{W})$ for the 


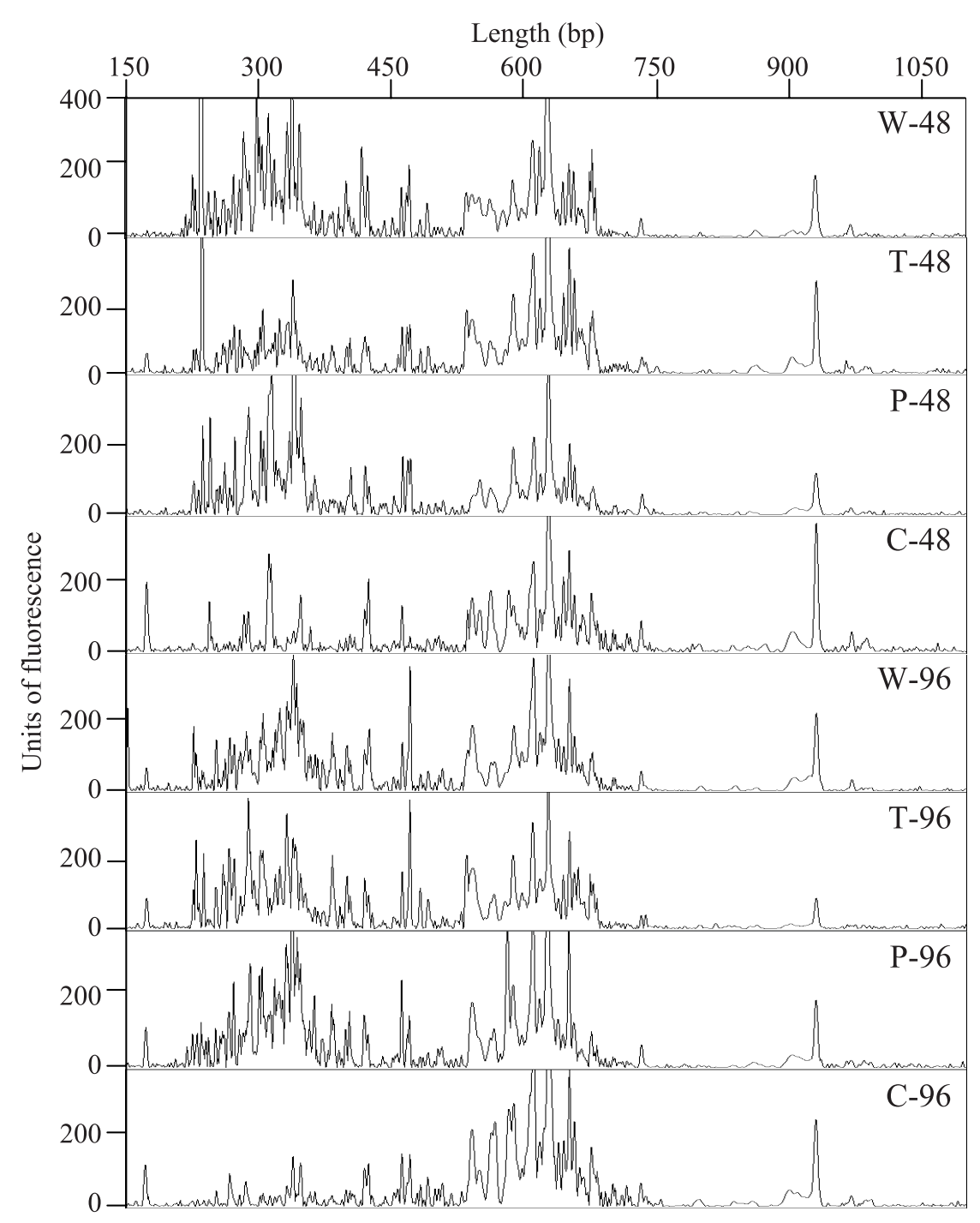

Figure 1. Example of ARISA profiles from soil microcosm exposed for 48 and $96 \mathrm{~h}$ to wild-type PBD6 tobacco (W), transplastomic PBD6 tobacco (T), wild-type Perustitza tobacco (P) and sterile water control (C). For each microcosm, five replicates were analyzed by ARISA of the bacterial community. Capillary electrophoresis separations were performed in triplicate.

Shannon-Weaver index $(P=0.01$ and 0.001 compared with $\mathrm{P}$ and $\mathrm{W}$ samples respectively), Simpson index ( $P=$ 0.05 and 0.027 compared with $\mathrm{P}$ and $\mathrm{W}$ samples) and Margalef index $(P=0.021$ and 0.015 compared with $\mathrm{P}$ and $\mathrm{W}$ samples). However, for all the ecological parameters, except the Margalef index, the differences between the soil bacterial communities exposed to root-released compounds of the non-transgenic cultivar Perustitza and those of the transplastomic and parental cultivars PBD6t and PBD6 were significantly $(P<0.05)$ higher than those between the transplastomic cultivar and the parental one (Tab. 1). This reflects the intrinsic biological differences between the PBD6 and the Perustitza cultivars, and indi- cates that the cultivar effect was more important in influencing the soil bacterial diversity.

ARISA peak data matrix was analyzed by Cluster Analysis, which yielded the tree shown in Figure 2. A 0.85 correlation coefficient resulted from the comparison of the cophenetic matrix obtained from the tree, with the original similarity matrix of the ARISA profiles, indicating the robustness of the tree. At $48 \mathrm{~h}$ of incubation, the ARISA profiles were mostly grouped in three different branches of the tree, according to the root-released compounds of the three tobacco cultivars they were exposed to. The ARISA profiles of the bacterial communities in the control treatments amended with water were 
L. Brusetti et al.

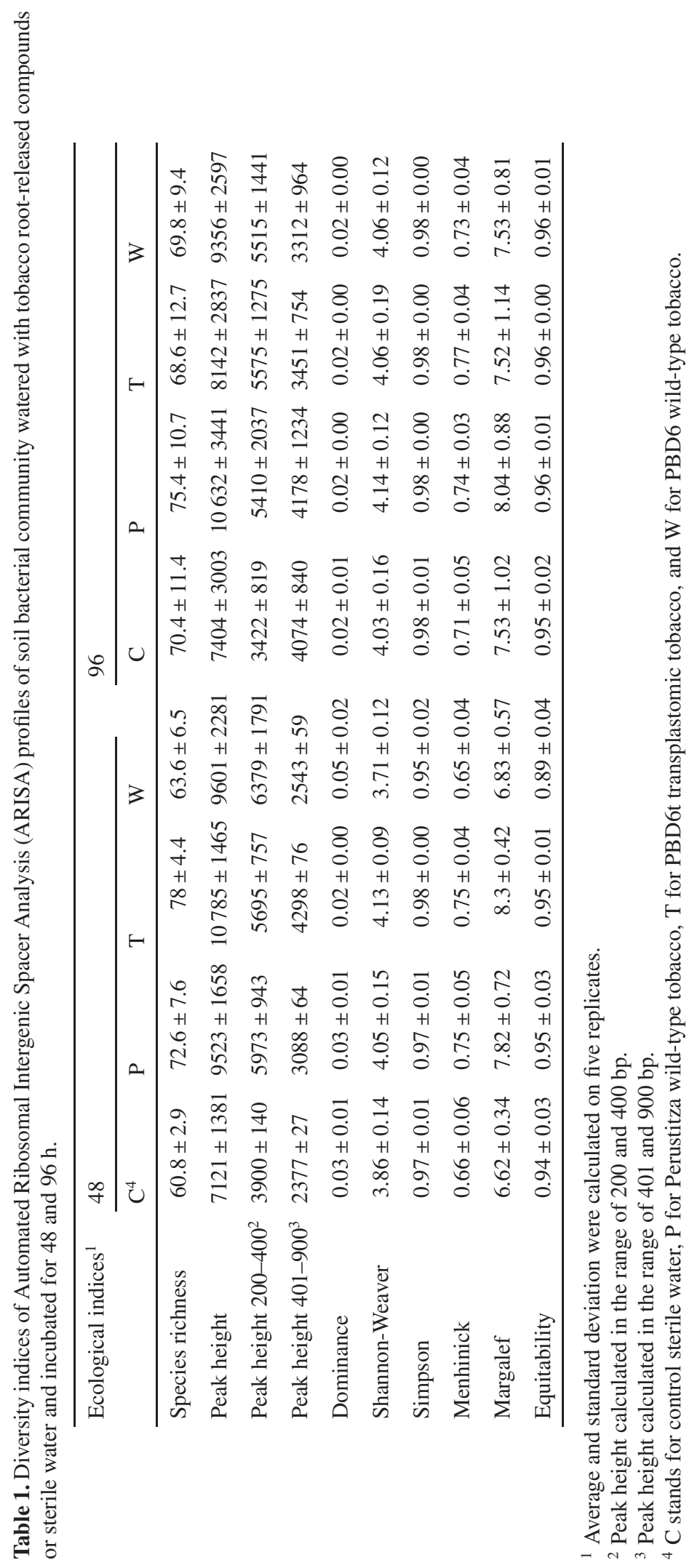




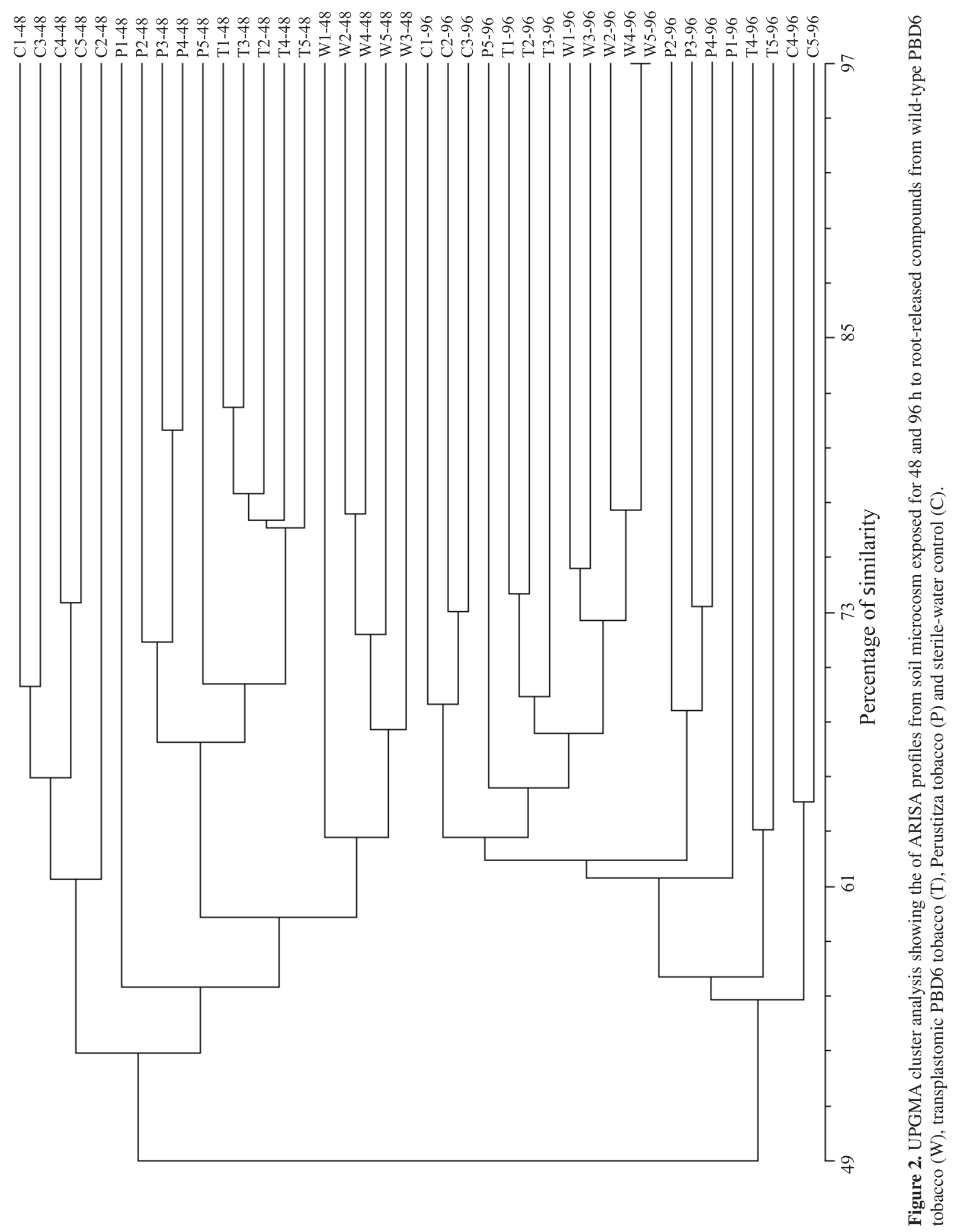




\section{Brusetti et al.}

grouped apart from those of soil exposed to root-released compounds. All the differences tended to disappear after $96 \mathrm{~h}$ of incubation (Fig. 2), since replicates of different treatments were grouped together, indicating a transient effect on the bacterial community structure determined by the exposure of the soil to the tobacco root-released compounds.

\section{CHEMICAL CHARACTERIZATION OF THE ROOT- RELEASED COMPOUNDS}

After 115 days of growth, the transplastomic PBD6t and the parental PBD6 tobacco cultivars had a comparable root biomass, with $13 \pm 0.8$ and $14.5 \pm 1.3 \mathrm{~g}$ of fresh weight per plant, respectively, and a shoot/root ratio of 5 and 4.9, respectively. The roots of Perustitza plants were slightly more developed, showing an average weight of $16 \pm 1.1 \mathrm{~g}$, with a shoot/root ratio of 4.5 . In order to characterize the water-soluble fraction of organic compounds released by roots, ${ }^{1} \mathrm{H}-\mathrm{NMR}$ analysis was performed in triplicate on one sample of root-released compounds from each plant genotype. It showed some quantitative and qualitative changes in a number of undefined chemical species between parental non-transgenic cultivar PBD6 and transplastomic PBD6t plants, as shown in representative scans in Figure 3. Several peaks in the 6$7 \mathrm{ppm}$ region typical of aromatic compounds were more abundant in the transplastomic cultivar, whereas the peak at $8.4 \mathrm{ppm}$, in a region typical of heterocyclic compounds, decreased greatly. Other differences in the NMR scans were detectable in the region between 3.5 and $5.5 \mathrm{ppm}$, and are probably related to certain carbohydrates and amino acids (Jackman and Sternhell, 1969).

HPLC analysis of organic acids, carbohydrates, and phenols confirmed different chemical fingerprints between PBD6t and the parental cultivar, but it was not useful for better characterization of root-released compounds, due to a lack of identity with the most common commercial standard molecules available for the assay (data not shown).

\section{In vitro transformation frequencies of constructed bacterial recipient strains}

Four soil and rhizosphere bacteria, namely Acinetobacter baylyi strain ADP1200 C1C2, Azospirillum brasilense strain RK290TG, Agrobacterium tumefaciens strain RK290TG, and Sinorhizobium meliloti strain RK290TG, were used as model recipients to assess the potential of root-released compounds as a source of transforming DNA. All these strains harbored the same construct described by Kay et al. (2002), i.e. the plastidic $r b c L$ and $a c c D$ genes flanking the aadA marker gene in the transplastomic tobacco plant. The construct was inserted in the chromosome in strain ADP1200 C1C2, whereas it was in a mobilizable plasmid in the three other strains.

None of the four bacterial strains gave rise to transformants when exposed to root-released compounds in filter transformation assays. Also, the exposure of three of four recipients to root-released compounds amended with plasmid pCLT, containing the donor rbcL-aadA$a c c D$ cassette of transplastomic tobacco, did not yield transformants, indicating that under these in vitro conditions, competence was not developed. In contrast, the good transformability of A. baylyi ADP1200 C1C2 was demonstrated by the transformation frequencies obtained after exposure of the strain to different donor DNAs (Tab. 2). The AadA marker was rescued with either the circular or linear pCLT plasmid at a frequency on the order of $10^{-2}$ per recipient cell. Transformation frequency decreased by two and three orders of magnitude using as donor tobacco leaf and root DNA, respectively, whereas it was on the order of $10^{-6}$ following exposure to transplastomic tobacco leaf homogenate. Moreover, the addition of root-released compounds to pCLT plasmid decreased the transformation frequency to $10^{-3}$, one order of magnitude lower with respect to the assays with pCLT alone. No transformants were obtained in any of the controls, neither with water nor with DNA from non-transgenic tobacco.

\section{PCR DETECTION OF WILD-TYPE AND TRANSPLASTOMIC TOBACCO DNA IN ROOT-RELEASED COMPOUND SOLUTIONS}

In order to understand the reasons for the negative results of the HGT experiments, the presence of potential transforming DNA in root-released compounds was investigated by PCR. Detection of tobacco plastidspecific sequences was performed with primer set plant $1 \mathrm{~F} /$ cloro3R, yielding a 123-bp fragment, whereas the detection of transplastomic-specific sequences was carried out with two primer sets, namely PromoF/R and aadA40F/PromoR, generating DNA amplicons of 333 and $129 \mathrm{bp}$, respectively. No PCR signals were obtained with both PromoF/R and plant $1 \mathrm{~F} / \mathrm{cloro} 3 \mathrm{R}$ primer pairs, whereas faint PCR products of the expected size were obtained with primer set aadA40F/PromoR in two of 50 samples tested, specifically designed to detect transformation events (data not shown).

\section{DISCUSSION}

To the best of our knowledge, there are no studies assessing the effects of root-released compounds collected 

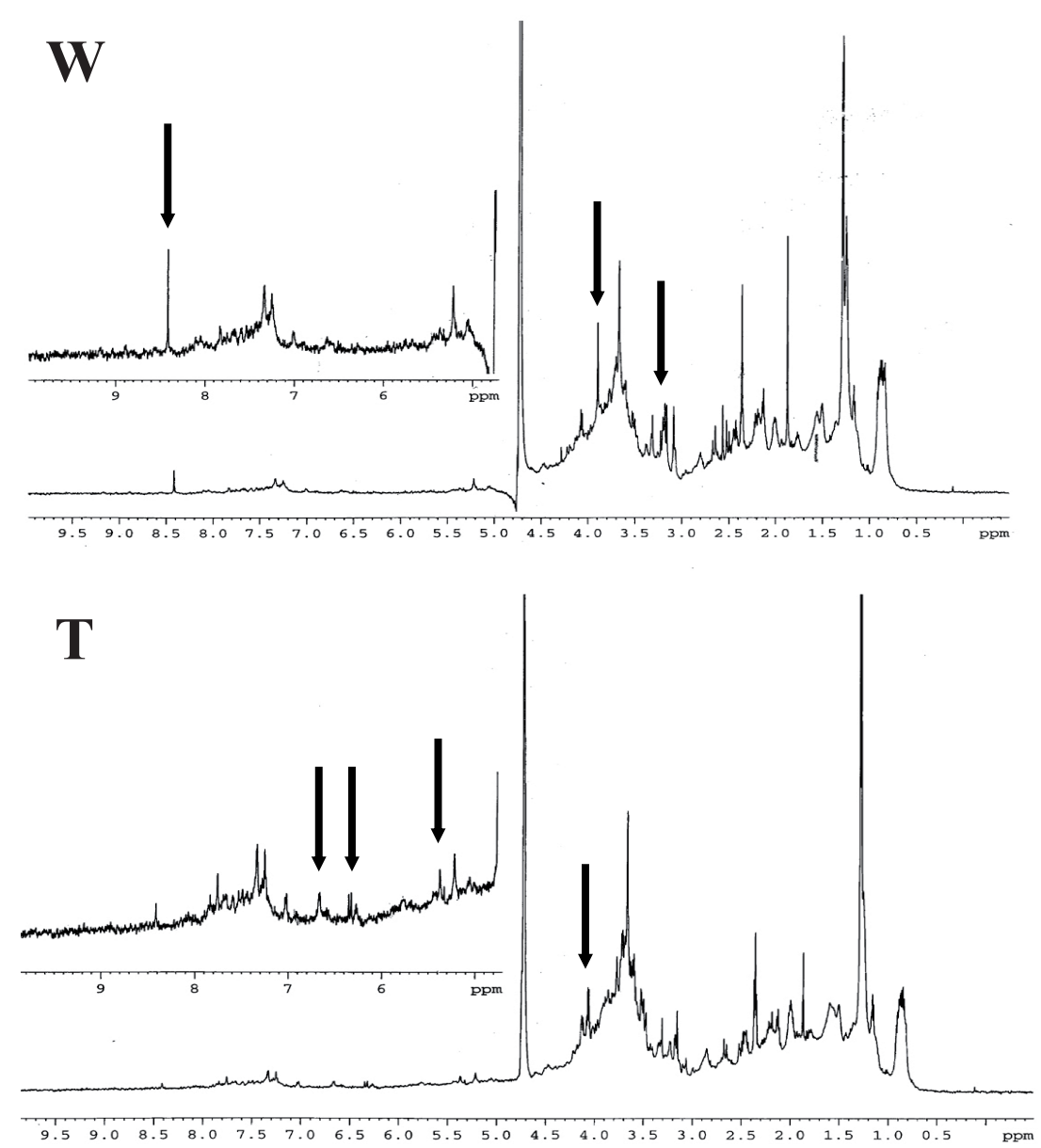

Figure 3. ${ }^{1} \mathrm{H}-\mathrm{NMR}(600 \mathrm{MHz})$ analysis of soluble fraction of root-released compounds collected from wild-type (W) and transplastomic PDB6 tobacco (T) plants; two representative scans are shown. Arrows indicate the variations in metabolite concentration that were observed in all five replicates.

from transplastomic plants on a soil bacterial community. And there is only one report in which the root-released compounds collected from transgenic Bt-176 maize roots added to root-free soils selected a bacterial community that was different that of the parental non-transgenic cultivar (Brusetti et al., 2004). Those experiments suggested that root-released compounds can be used to study the effect of other transgenic plants, such as transplastomic tobacco, on the soil bacterial community.

The use of the root-released compounds instead of the entire plant root has some advantages but also limitations in assessing the effects of a plant on the soil bacterial community. Limitations are due to the absence of the root, which is important for the determination of the community structure. However, an important advantage is that a given variation observed in the structure of the bacterial community could be directly correlated with the chemical composition of the root-released compounds
(Mansouri et al., 2002; Oger et al., 1997; 2000; Savka and Farrand, 1997). Such studies could provide an explanation for the observation that the root-associated bacterial community changes in response to different plant cultivars (Chiarini et al., 1998; Gomes et al., 2001; Heuer et al., 2002; Smalla et al., 2001; Smit et al., 2001) and seasons (Baudoin et al., 2002; Brusetti et al., 2004; Heuer et al., 2002). Considering that the soil volume influenced by root-released compounds is limited to the first $2-4 \mathrm{~mm}$ of the rhizosphere (Falchini et al., 2002), our experimental design of soil watering with more than $400 \mu \mathrm{g} \cdot \mathrm{mL}^{-1}$ of root-released organic carbon derived from transplastomic tobacco, corresponded to a condition that may occur under natural environments (Lynch and Whipps, 1990) and can simulate the natural release in the rhizosphere.

The analysis of the bacterial community structure of the watered soil was done by ARISA, a highly reproducible community fingerprinting analysis, sensitive to 


\section{Brusetti et al.}

Table 2. Transformation frequencies of A. baylyi strain ADP1200C1C $2^{1}$ exposed to pCLT plasmid, to different sources of transplastomic donor DNA and to root-released compounds from transplastomic tobacco.

\begin{tabular}{|c|c|c|c|c|c|}
\hline Donor DNA & $\begin{array}{c}\text { Amount of } \\
\text { material used }\end{array}$ & $\begin{array}{l}\text { No. of donor } \\
\text { genes per assay }\end{array}$ & $\begin{array}{l}\text { No. of transformants } \\
\text { per assay }^{2}\end{array}$ & $\begin{array}{c}\text { Transformants } \\
\text { per target gene }{ }^{2}\end{array}$ & $\begin{array}{l}\text { Transformation } \\
\text { frequency }^{2}\end{array}$ \\
\hline Circular pCLT plasmid & $1 \mu \mathrm{g}$ DNA & $1.3 \times 10^{11}$ & $(1.2 \pm 0.3) \times 10^{8}$ & $(9.8 \pm 2.6) \times 10^{-4}$ & $(1.3 \pm 0.1) \times 10^{-2}$ \\
\hline Linear pCLT plasmid & $1 \mu \mathrm{g}$ DNA & $1.3 \times 10^{11}$ & $(1.1 \pm 0.1) \times 10^{8}$ & $(8.4 \pm 0.1) \times 10^{-4}$ & $(1.2 \pm 0.2) \times 10^{-2}$ \\
\hline $\begin{array}{l}\text { Total DNA from } \\
\text { transplastomic leaf tissue }\end{array}$ & $5 \mu \mathrm{g}$ DNA & $5.5 \times 10^{9}$ & $(1.1 \pm 0.1) \times 10^{6}$ & $(2.0 \pm 0.2) \times 10^{-4}$ & $(1.3 \pm 0.2) \times 10^{-4}$ \\
\hline $\begin{array}{l}\text { Total DNA from } \\
\text { transplastomic root tissue }\end{array}$ & $5 \mu \mathrm{g}$ DNA & n.d. & $(1.5 \pm 0.2) \times 10^{5}$ & n.a. & $(1.6 \pm 0.2) \times 10^{-5}$ \\
\hline $\begin{array}{l}\text { Transplastomic leaf } \\
\text { homogenate }\end{array}$ & $100 \mu \mathrm{L}(500 \mathrm{mg})$ & n.d. & $(1.2 \pm 0.1) \times 10^{4}$ & n.a. & $(1.4 \pm 0.3) \times 10^{-6}$ \\
\hline Root-released compounds & $100 \mu \mathrm{L}$ & n.d. & 0 & n.a. & $<10^{-8}$ \\
\hline $\begin{array}{l}\text { Root-released compounds }+ \\
\text { circular pCLT }\end{array}$ & $\begin{array}{c}100 \mu \mathrm{L} \\
1 \mu \mathrm{g} \text { DNA }\end{array}$ & $\begin{array}{c}\text { n.d. } \\
1.3 \times 10^{11}\end{array}$ & $(2.9 \pm 0.2) \times 10^{7}$ & n.a. & $(3.3 \pm 0.8) \times 10^{-3}$ \\
\hline $\begin{array}{l}\text { Total DNA from non- } \\
\text { transgenic leaf tissue }\end{array}$ & $5 \mu \mathrm{g}$ DNA & 0 & 0 & 0 & $<10^{-8}$ \\
\hline
\end{tabular}

${ }^{1}$ Recipients were approximately $10^{7} \mathrm{CFU}$.

${ }^{2}$ Data are means \pm standard deviations of three experiments; n.d.: not determinable; n.a.: not applicable.

small changes in the structure of bacterial communities at the intraspecific level (Cardinale et al., 2004; Daffonchio et al., 2003; Fisher and Triplett, 1999). ARISA indicated that the compounds released by the tobacco roots changed the soil bacterial community structure after $48 \mathrm{~h}$ of exposure. The compounds released by the root of the transplastomic cultivar PBD6t selected a somewhat different bacterial community with respect to the parental cultivar, confirming what had already been observed with several other transgenic plants (Brusetti et al., 2004; Di Giovanni et al., 1999; Dunfield and Germida, 2001; Gyamfi et al., 2002; Siciliano and Germida, 1999). However, considering the differences observed between nontransgenic cultivars (Perustitza and PBD6), we cannot exclude that the differences between the transplastomic PBD6t and the parental PBD6 is due to differences in the genotype, rather than the presence of the transgene. Although the differences in the bacterial community structure were in both dominant and non-dominant ARISA peaks, and were consistently found in microcosm replicates (Fig. 1), they did not determine changes in the diversity indices, and did not affect the dominance and richness of the community. Moreover the real biological significance of the slight differences revealed by some ecological indices remains strictly unknown (Tab. 1).
The effect of the root-released compounds on the bacterial community structure were transient, since after $96 \mathrm{~h}$ of incubation, ARISA patterns of replicate microcosms exposed to the same root-released compounds tended to be more similar to those exposed to solutions from different cultivars (Fig. 1). However we cannot extend these results to the field situation, since in that case soil bacteria are exposed to root-released compounds continuously for the entire plant-growing period. The question of a longer exposure of soil bacterial flora should be addressed with a different experimental design, as done by other authors (Brusetti et al., 2004; Donegan et al., 1995; Dunfield and Germida, 2003; Sessitsch et al., 2003).

To test the hypothesis that the slight effects we observed on the structure of the soil bacterial community could be due to some differences in the plant root-released compounds, we examined their chemical complexity. A preliminary comparison between chemical patterns of transplastomic and parental non-transgenic tobacco root-released compounds showed some differences in the abundance of different classes of molecules. The biological reasons of these differences as well as the consequences on specific microorganisms are yet unknown and should be investigated further in other studies. 
To evaluate if DNA, eventually present in the rootreleased compounds of transplastomic tobacco, could be a source of bacterial transformation, we used the highly transformable A. baylyi ADP1, for which the acquisition of recombinant plant DNA has been repeatedly demonstrated, and three other soil and rhizosphere bacteria among which two that were reported to be transformable (Courtois et al., 1988; Demanèche et al., 2001).

All the recipient strains constructed failed to give transformants following exposure to root-released compounds. Control experiments with the recipient strain A. baylyi ADP1200 C1C2 containing the docking site in the chromosome, indicated that this strain was transformable, since it showed the same transformation frequencies as analogous strains with the same recombination receptor site located on a plasmid (de Vries et al., 2004; Kay et al., 2002). In contrast, the other recipients failed to give transformants, even in the presence of donor DNA. In the filter transformation protocol used, for which is not necessary to know the exact time period of competence since cells grow to the competent state during the incubation period, no transformants were observed, also in presence of root-released compounds. A low amount of plastid DNA and rapid DNA degradation, combined with the presence of some transformation inhibitors in the root-released compounds, can explain the absence of transformants. The latter point was supported by the lower transformation frequency obtained following exposure to root-released compounds supplemented with donor pCLT DNA, compared to the transformation frequencies determined with pCLT DNA alone. Using PCR, the $129 \mathrm{bp}$ transgene fragment was observed occasionally, whereas the $333 \mathrm{bp}$ fragment never was.

To our knowledge this is the first time that rootreleased compounds were investigated for DNA detection, although sloughing off of root cap cells from the root tip is known to be an important process assisting the growing root in penetrating soil. However, Tepfer et al. (2003) showed gene transfer in the rhizosphere by coculturing recipient Acinetobacter strains and intact roots. They also showed that roots subjected to stress, induced by pre-culturing roots in sterile water or medium deficient in micronutrients, resulted in a higher frequency of DNA transfer. Although we similarly subjected the roots to stress by immersing them in distilled water for the collection of the root-released compounds, we were unable to detect transformants.

In conclusion, we observed that root-released compounds of a transplastomic tobacco influenced the soil bacterial community differently from the parental counterpart, which may be due to a modified chemical composition. However, this effect appeared to be transient. DNA was observed in the root-released compounds only in two out of 50 PCR reactions tested, and only short frag- ments were amplified, suggesting that the roots of plants grown in hydroponic condition released very little DNA, and consequently the potential for natural transformation was very low. However, for a risk assessment analysis, and thus for a quantitative estimate of the potential of HGT by root-released DNA, further experiments under more realistic conditions should be performed.

\section{MATERIALS AND METHODS}

\section{Bacterial strains and culture conditions}

Escherichia coli XL1-Blue (Stratagene, Milan, Italy) was the recipient strain for the cloning experiment. A. baylyi strain ADP1200, a derivative of strain ADP1 (Kok et al., 1999), A. brasilense SPF94 (Rif $\left.{ }^{\mathrm{R}}\right)$, A. tumefaciens LBA4404 (Rif ${ }^{\mathrm{R}}$ ), and S. meliloti RF1 (USDA $1002 \mathrm{Rif}^{\mathrm{R}}$ ) were used for the construction of recipient strains harboring sequences homologous to those of transplantomic tobacco. E. coli, A. baylyi and A. tumefaciens were cultured in LB medium (10 g.. $\mathrm{L}^{-1}$ Bacto tryptone, 5 g.L $\mathrm{L}^{-1}$ yeast extract, 5 g. $\left.\mathrm{L}^{-1} \mathrm{NaCl}\right)$, A. brasilense in antibiotic broth (5 g.L $\mathrm{L}^{-1}$ peptone, 1.5 g.L $\mathrm{L}^{-1}$ yeast extract, 1.5 g.L $\mathrm{L}^{-1}$ meat extract, 1 g.. $\mathrm{L}^{-1}$ dextrose, $3.5 \mathrm{~g} . \mathrm{L}^{-1} \mathrm{NaCl}$, 3.68 g.L $\mathrm{L}^{-1} \mathrm{~K}_{2} \mathrm{HPO}_{4}, 1.32$ g.L $\mathrm{L}^{-1} \mathrm{H}_{2} \mathrm{KPO}_{4}, \mathrm{pH}$ 7.0), and S. meliloti in TY medium (5 g.L $\mathrm{L}^{-1}$ tryptone, 3 g.L $\mathrm{L}^{-1}$ yeast extract, 0.5 g.L $\left.\mathrm{L}^{-1}, \mathrm{CaCl}_{2} \cdot 2 \mathrm{H}_{2} 0, \mathrm{pH} 7.2\right)$. All strains were grown at $30{ }^{\circ} \mathrm{C}$, except E. coli grown at $37{ }^{\circ} \mathrm{C}$. Media were supplemented, when necessary, with appropriate antibiotics. Working antibiotic concentrations were $50 \mu \mathrm{g} . \mathrm{mL}^{-1}$ for kanamycin, spectinomycin and rifampicin, $12.5 \mu \mathrm{g} \cdot \mathrm{mL}^{-1}$ tetracycline and $5 \mu \mathrm{g} \cdot \mathrm{mL}^{-1}$ chloramphenicol.

\section{Plant materials and collection of root-released compounds}

For this study, tobacco seeds of transplastomic PBD6t, parental non-transgenic PDB6 and Perustitza cultivars were used. PBD6 is a Paraguay dark tobacco, while Perustitza is an Oriental cultivar. Transplastomic tobacco PBD6t was transformed with the insertion in the plastid genome of the aadA gene, conferring resistance to both spectinomycin and streptomycin antibiotics (Kay et al., 2002). Tobacco seeds were germinated on $1 \%$ sterile agar containing full-strength Hoagland solution. Transplastomic plants were selected by the presence in the agar of $100 \mathrm{mg} . \mathrm{L}^{-1}$ of spectinomycin. The plants were grown in a phytotron with a $16 \mathrm{~h}$ day-length, with a PAR of $250 \mu \mathrm{mol} . \mathrm{m}^{-2} \cdot \mathrm{s}^{-1}, 26-20{ }^{\circ} \mathrm{C}$ day-night cycles, $70 \%$ relative humidity. Three-week-old plants were transferred to aerated, sterile, full-strength Hoagland solution, and grown for 115 days, eight plants in $500 \mathrm{~mL}$ for three 


\section{Brusetti et al.}

weeks, and then eight plants in $10 \mathrm{~L}$. The nutrient solution was renewed every 7 days.

Collection of root-released compounds was performed according to Fan et al., (1997), with 115-day-old plants. Plants roots were removed from the nutrient solution, their roots rinsed with distilled water, and treated for 1 min with 0.01 g.L. $\mathrm{L}^{-1}$ Micropur (Katadyn, Wallisellen, Switzerland), an antimicrobial agent (Gries et al., 1995). After the antimicrobial treatment, the roots were rinsed again with distilled water. Roots of six plants were immersed in a tank filled with $500 \mathrm{~mL}$ of distilled water for the collection of root-released compounds; three different tanks of plant for both PBD6t and PBD6 were used, for a total of 18 plants for each cultivar. The collection of the root-released compounds started $2 \mathrm{~h}$ after the beginning of the photoperiod and lasted for $4 \mathrm{~h}$, for 6 consecutive days. Every day, at the end of the collection period, plants were replaced in the nutrient solution until the next collection. At the end of the last collection of root-released compounds, root and shoot weight was recorded.

After each collection, the liquid obtained was filtered through four layers of gauze and pooled. Two liters of the root-released compound solution were concentrated to dryness by lyophilization, and the dry material obtained was resuspended in $15 \mathrm{~mL}$ of distilled water. The suspension was filtered on $0.45 \mu \mathrm{m}$ cellulose acetate filters to separate the water soluble from the insoluble fraction. The filters were pre-treated with $5 \mathrm{~mL}$ of $200 \mathrm{mM} \mathrm{NaCl}$ and rinsed with $200 \mathrm{~mL}$ of distilled water. The insoluble fraction retained on the filter was dried by lyophilization, recovered and weighed. The content of organic $\mathrm{C}$ in the soluble and insoluble fraction was measured spectrophotometrically, determining the absorbance at $578 \mathrm{~nm}$ of CrIII, after wet oxidation with $0.25 \mathrm{~N} \mathrm{~K}_{2} \mathrm{Cr}_{2} \mathrm{O}_{7}$ and concentrated $\mathrm{H}_{2} \mathrm{SO}_{4}$ at $120{ }^{\circ} \mathrm{C}$ for $90 \mathrm{~min}$. Glucose was utilised as a standard (Wiren et al., 1995).

\section{Effect of root-released compounds on rhizosphere bacterial community}

For the microcosm experiments, the water-soluble fraction of the root-released compounds was mixed with the insoluble fraction, and then divided in aliquots containing $225 \mu \mathrm{g}$ organic $\mathrm{C}$ of the water-soluble fraction and $200 \mu \mathrm{g}$ organic $\mathrm{C}$ of water-insoluble fraction. This mixture, named root-released compounds, was used to amend soil microcosms.

One hundred grams of the same soil used for plant cultivation (30\% clay, $40 \%$ silt and $20 \%$ sand; $10 \%$ organic matter) was mixed carefully and homogenized. Two-gram aliquots of this soil were placed aseptically in 90 sterile glass tubes that had two drainage layers (each about $2 \mathrm{~cm}$ thick) made of sterile glass wool on a layer of sterile glass beads (average diameter $3 \mathrm{~mm}$ ) at the bottom of the glass tube. Three series of five replicated microcosms were watered with the root-released compound suspension collected from PDB6, PDB6t and Perustitza tobacco cultivars. Another set of tubes, acting as the control, was watered with sterile water. Microcosms were incubated at $28{ }^{\circ} \mathrm{C}$ and sampled after 48 and $96 \mathrm{~h}$ of incubation. For DNA extraction, $500 \mathrm{mg}$ of soil was treated with a Fast DNA SPIN kit (Bio101, Vista, CA) according to the manufacturer's instructions.

Soil bacterial community structure was characterized by ARISA (Fisher and Triplett, 1999) using the PCR primers, protocol, and separation in a capillary sequencer as described in detail by Cardinale et al. (2004). The electrophoresis runs of all samples were performed in triplicate.

A binary peak matrix was generated from the normalized ARISA profiles and subjected to Cluster analysis. Since each sample was analyzed in three independent runs, only peaks confirmed in all the three runs were considered in the peak matrix. Pairwise distances were calculated with the SimQual function of the NTSYSpc 2.01 computer program (Applied Biostatistics Inc., USA), by employing the Jaccard coefficient for two-state data, and strain clustering was performed by UPGMA analysis. The significance of the resulting UPGMA tree was checked by comparing the original similarity matrix with the cophenetic similarity matrix by using the Mantel test. Seven diversity indices, including Species Richness, Dominance, Shannon-Weaver, Simpson, Menhinick, Margalef, and Equitability, were calculated from the normalized peak matrix by using the PAST program (Hammer et al., 2001), as explained in Brusetti et al. (2006). This provided a more detailed description of the diversity within samples (Magurran, 1988). Statistical significance of each diversity index between treatments was calculated with the analysis of variance.

\section{${ }^{1} \mathrm{H}$-NMR and HPLC analysis of the water-soluble fraction of root-released compounds}

${ }^{1} \mathrm{H}-\mathrm{NMR}$ analysis was performed in triplicate on the water-soluble fraction of the root-released compounds obtained from transplastomic tobacco PDB6t and the parental non-transgenic cultivar PDB6. The watersoluble fraction was concentrated to dryness by lyophilisation and redissolved in $\mathrm{D}_{2} \mathrm{O}$ (Aldrich Chemical Company, Milwaukee, USA). $\mathrm{pH}$ of the solution was kept at 7.5 by addition of $\mathrm{DCl}$.

For the ${ }^{1} \mathrm{H}-\mathrm{NMR}$ analysis, samples of $600 \mu \mathrm{L}$ of $\mathrm{D}_{2} \mathrm{O}$ (99.9\% isotopic purity, ISOTEC, USA) containing $0.9 \mathrm{mg}$ of organic $\mathrm{C}$ were used. Solutions were immediately transferred in $5 \mathrm{~mm}$ O.D. NMR tubes (Wilmad, 
USA). NMR spectra were acquired at $25{ }^{\circ} \mathrm{C}$ on a Bruker AMX-600 spectrometer (Bruker Spektrospin AG, Rheinstetten, Germany), equipped with a $5 \mathrm{~mm}$ inverse probe and $\mathrm{z}$-axis gradients, using standard acquisition parameters (12 ppm spectral width, $1.3 \mathrm{~s}$ relaxation delay). Solvent suppression was achieved by presaturation of the residual HDO signal. Spectra were referenced to external DSS, set at 0 ppm.

HPLC analysis was performed on this soluble fraction. Analytical protocols of McBee and Manes (1983), Andersen and Pedersen (1983), and Gancedo and Luth (1986) were used for carbohydrates, phenols and organic acids, respectively.

\section{Plasmids and plasmid constructions}

Plasmid pCLT, an ampicillin-resistant cloning vector, containing a spectinomycin and streptomycin resistance gene ( $\operatorname{aad} A)$, flanked with sequences from plastid genes $r b c L$ and $a c c D$, and plasmid $\mathrm{pBaB} 2$, a RSF1010-derived broad-host-range vector, containing part of the $r b c L$ and $a c c D$ genes (Kay et al., 2002), were kindly provided by P. Simonet. Plasmid pZR80-2C1C2 was generated from plasmid pZR80-2, a derivative of the integrative pZR80 vector (Kok et al., 1999) lacking an ampicillin resistance gene. A 2.5-kb fragment (named C1C2) was amplified by PCR from $\mathrm{pBAB} 2$ with primers chloro1 and chloro2 (Kay et al., 2002), complementary to the $r b c L$ and $a c c D$ genes, respectively. The fragment, after blunting and dephosphorylation, was ligated into pZR80-2 digested with $S t u I$, yielding plasmid pZR80-2C1C2. Plasmid pRK290TG was generated by introducing the $\mathrm{C} 1 \mathrm{C} 2$ fragment into the EcoRI site of the broad-host-range cloning vector pRK290, which was mobilizable by pRK2013 (Figurski and Helinski, 1979).

\section{Construction of recipient strains alternative to $A$. baylyi strain ADP1200C1C2}

Recipient strains were designed to contain sequences homologous to plastid genes $r b c L$ and $a c c D$, in order to allow homologous recombination-mediated integration of the transgene aadA when transformed with transplastomic tobacco DNA. For increased strain stability, the docking site of marker rescue transformation was localized in the chromosome of A. baylyi ADP1200. This strain harbors on the chromosome, between the $\operatorname{lip} B$ and lipA genes of the lipase operon, a 5'-truncated aph $3 A$ gene (kanamycin resistance). In order to introduce the rbcl-accD cassette into the A. baylyi ADP1200 lipBA operon, the SpeI-linearized pZR80-2C1C2 plasmid was introduced in A. baylyi ADP1200 by natural transformation and selection on kanamycin. Plasmid pRK290TG was introduced into A. brasilense SPF94, A. tumefaciens LBA 4404, and $S$. meliloti RF1 by triparental mating involving helper strain E. coli (pRK2013) and by selecting for rifampicin and tetracycline resistance. The derived strains were A. brasilense strain RK290TG, A. tumefaciens strain RK290TG and S. meliloti strain RK290TG. The presence of the tobacco cassette in the transformed strains was confirmed by standard restriction and PCR techniques.

\section{Donor DNA and plant material for transformation experiments}

Plasmid DNA was prepared from E. coli using the QIAprep Spin Miniprep kit (Qiagen, Milan, Italy). Linearized pCLT was obtained by restriction at the $S c a$ I site. Total tobacco DNA extraction started with fine grinding of leaf or root tissues in a sterile mortar with liquid nitrogen. Three grams of the resulting powder were transferred to a sterile $50 \mathrm{~mL}$ falcon tube, mixed with $5 \mathrm{~mL}$ of DNA extraction buffer $(500 \mathrm{mM} \mathrm{NaCl}, 100 \mathrm{mM}$ Tris$\mathrm{HCl} \mathrm{pH} \mathrm{7.5,} \mathrm{and} 50 \mathrm{mM}$ EDTA pH 7.5), and mixed with $0.5 \mathrm{~mL}$ of $20 \%$ SDS and incubated at $65{ }^{\circ} \mathrm{C}$ for $15 \mathrm{~min}$. An equal volume of phenol:chloroform:isoamyl alcohol (25:24:1) was added and, after mixing the sample was centrifuged $(7000 \times g, 10 \mathrm{~min}$, at room temperature). After transferring the aqueous phase to a new tube, the samples were mixed with 1 volume of isopropanol, mixed and centrifuged $\left(7000 \times g, 20 \mathrm{~min}, 4^{\circ} \mathrm{C}\right)$. The DNA pellet was briefly dried at room temperature, resuspended in $1 \mathrm{~mL}$ of sterile water, and then $500 \mu \mathrm{L}$ sodium-acetate ( $3 \mathrm{M})$ were added. DNA from the aqueous phase was precipitated with 1 volume of isopropanol, centrifuged, washed with $70 \%$ ethanol, and resuspended in $200 \mu \mathrm{L}$ of sterile water. Two $\mu \mathrm{L}$ RNase A (10 mg. $\left.\mathrm{mL}^{-1}\right)$ were added to the samples. Then they were incubated for $1 \mathrm{~h}$ at $37^{\circ} \mathrm{C}$, and stored frozen at $-20{ }^{\circ} \mathrm{C}$. Extracted DNA was quantified by $\mathrm{UV}_{260}$ and/or by agarose gel electrophoresis using lambda phage DNA as a concentration marker. Fresh tobacco leaf homogenate was prepared as follows. Five grams of leaf tobacco were ground in a mortar with liquid $\mathrm{N}_{2}$, transferred to a sterile tube, and mixed with $10 \mathrm{~mL}$ of distilled water. After $30 \mathrm{~min}$ incubation on ice, the plant material was centrifuged $(10000 \times \mathrm{g}, 15 \mathrm{~min}$, $4{ }^{\circ} \mathrm{C}$ ) and the resulting supernatant was filtered through a $0.2 \mu \mathrm{m}$ filter.

\section{Marker rescue transformation assay and PCR verification of transformants}

Filter transformation experiments were carried out as described by Nielsen et al. (2004). One hundred $\mu \mathrm{L}$ of frozen competent cells (approximately $10^{7} \mathrm{CFU}$ ) were 


\section{Brusetti et al.}

exposed to $1 \mu \mathrm{g}$ of pCLT or $5 \mu \mathrm{g}$ of purified plant DNA or $100 \mu \mathrm{L}$ of leaf homogenate or $100 \mu \mathrm{L}$ of rootreleased compounds. Colony forming units were determined by plating on LB agar plates supplemented with kanamycin $\left(50 \mu \mathrm{g} . \mathrm{mL}^{-1}\right)$, whereas transformants were selected on kanamycin $\left(50 \mu \mathrm{g} . \mathrm{mL}^{-1}\right)$ and spectinomycin $\left(100 \mu \mathrm{g} . \mathrm{mL}^{-1}\right)$. The colonies were counted after $48 \mathrm{~h}$ of incubation. The transformation frequency was determined as the ratio of transformants to the total count. Each assay was performed in triplicate. Controls were made with water and non-transgenic tobacco DNA. The detection limit of transformation was the reciprocal value of the total recipient cells in the transformation assay. The restoration of aadA in antibiotic-resistant transformants was verified by PCR analysis with primers Promo F (5'-ATCTTTCTATTGTTGTCTTGGAT-3') and Promo R (5'-GGTCACCGTAACCAGCAAATCAA-3'), sited, respectively, just upstream of $\mathrm{P}_{\mathrm{rrn}}$ promoter and in the aadA gene, yielding a $333 \mathrm{bp}$ fragment.

Transformability of strains A. brasilense RK290TG, A. tumefaciens RK290TG, and S. meliloti RK290TG was checked using the filter protocol. To increase the limit of detection, $1 \mathrm{~mL}$ of cells (O.D. 0.8), instead of $100 \mu \mathrm{L}$, were exposed to $10 \mu \mathrm{g}$ of pCLT and placed on a GSWP 90-mm filter placed on top of appropriate strain-specific medium. Each assay was performed in triplicate. Transformants were selected on rifampicin $\left(50 \mu \mathrm{g} \cdot \mathrm{mL}^{-1}\right)$, tetracycline $\left(12.5 \mu \mathrm{g} \cdot \mathrm{mL}^{-1}\right)$ and spectinomycin $\left(100 \mu \mathrm{g} . \mathrm{mL}^{-1}\right)$. Recipient cell titres were determined by plating on agar medium supplemented with rifampicin $\left(50 \mu \mathrm{g} \cdot \mathrm{mL}^{-1}\right)$ and tetracycline $\left(12.5 \mu \mathrm{g} \cdot \mathrm{mL}^{-1}\right)$.

\section{Detection of tobacco DNA released from roots}

Primer sets Promo F/R and aadA40F/PromoR, generating fragments of 333 and $129 \mathrm{bp}$, respectively, were used for detecting transplastomic-specific sequences. The sequence of aadA40F was the following: 5'CTATCAGAGGTAGTTGGCGT-3'. The primers for the detection of the tobacco chloroplast gene (the non-coding region between the $\operatorname{trn} T$ and $\operatorname{trn} F$ genes), generating a 123 bp amplicon, were plant $1 \mathrm{~F}$ (Einspanier et al., 2001) and cloro 3R (5'-GATTTGGCTCAGGATTGCC-3'). PCR reactions were carried out in a final volume of $50 \mu \mathrm{L}$; PCR working concentrations were the following: $1 \mathrm{X}$ PCR buffer, $1.5 \mathrm{mM}$ of $\mathrm{MgCl}_{2}, 200 \mu \mathrm{M}$ of each dNTPs, $0.5 \mu \mathrm{M}$ of each primer, 2 unit of Taq DNA polymerase (Invitrogen, Milan, Italy), $2.5 \mu \mathrm{L}$ of root-released compounds as template. For each type of PCR reaction, $100 \mu \mathrm{L}$ of root-released compounds was assayed. Thermal conditions consisted of an initial denaturation step of $4 \mathrm{~min}$ at $95^{\circ} \mathrm{C}$, followed by 40 cycles consisting in $40 \mathrm{~s}$ at $94{ }^{\circ} \mathrm{C}, 40 \mathrm{~s}$ at $57^{\circ} \mathrm{C}$ and $40 \mathrm{~s}$ at $72{ }^{\circ} \mathrm{C}$. The final extension step was of 3 min at $72{ }^{\circ} \mathrm{C}$. PCR products were analyzed by standard agarose gel electrophoresis.

\section{ACKNOWLEDGEMENTS}

The work was supported by the EU project TRANSBAC QLK3-CT-2001-02242 (5th RTD Program). Financial support came also from the Fondazione Diritti Genetici, Italy, project "Organismi geneticamente modificati ed alimentazione: valutazione degli effetti diretti sull'ospite e sulla microflora intestinale" funded by the Cariplo Foundation, Italy.

Received February 8, 2007; accepted November 12, 2007.

\section{REFERENCES}

Andersen JM, Pedersen WB (1983) Analysis of plant phenolics by High-Performance Liquid Chromatography. $J$. Chromatogr. 259: 131-139

Baudoin E, Benizri E, Guckert A (2002) Impact of growth stage on the bacterial community structure along maize roots as determined by metabolic and genetic fingerprinting. Appl. Soil Ecol. 19: 135-145

Brusetti L, Francia P, Bertolini C, Pagliuca A, Borin S, Sorlini C, Abruzzese A, Sacchi G, Viti C, Giovannetti L, Giuntini E, Bazzicalupo M, Daffonchio D (2004) Bacterial communities associated with the rhizosphere of transgenic Bt 176 maize (Zea mays) and its non transgenic counterpart. Plant Soil 266: 11-21

Brusetti L, Borin S, Mora D, Rizzi A, Raddadi N, Sorlini C, Daffonchio D (2006) Usefulness of length heterogeneityPCR for monitoring lactic acid bacteria succession during maize ensiling. FEMS Microbiol. Ecol. 56: 154-164

Cardinale M, Brusetti L, Quatrini P, Borin S, Puglia AM, Rizzi A, Zanardini E, Sorlini C, Corselli C, Daffonchio D (2004) Comparison of different primer sets for the Automated Ribosomal Intergenic Spacer Analysis (ARISA) of complex bacterial communities. Appl. Environ. Microbiol. 70: 61476156

Chiarini L, Bevivino A, Dalmastri C, Nacamulli C, Tabacchioni S (1998) Influence of plant development, cultivar and soil type on microbial colonisation of maize roots. Appl. Soil Ecol. 8: 11-18

Courtois J, Courtois B, Guillaume J (1988) High-frequency transformation of Rhizobium meliloti. J. Bacteriol. 170: 5925-5927

Daffonchio D, Cherif A, Brusetti L, Rizzi A, Mora D, Boudabous A, Borin S (2003) Nature of polymorphisms in 16S-23S rRNA gene intergenic transcribed spacer fingerprinting of Bacillus and related genera. Appl. Environ. Microbiol. 69: 5128-5137 
Daniell H, Datta R, Varma S, Gray S, Lee SB (1998) Containment of herbicide resistance through genetic engineering of the chloroplast genome. Nature Biotechnol. 16: 345-348

De Vries J, Herzfeld T, Wackernagel W (2004) Transfer of plastid DNA from tobacco to the soil bacterium Acinetobacter sp. by natural transformation. Mol. Microbiol. 53: 323-334

Demanèche S, Kay E, Gourbiere F, Simonet P (2001) Natural transformation of Pseudomonas fluorescence and Agrobacterium tumefaciens in soil. Appl. Environ. Microbiol. 67: $2617-1621$

Di Giovanni GD, Watrud LS, Seidler RJ, Widmer F (1999) Comparison of parental and transgenic alfalfa rhizosphere bacterial communities using Biolog GN metabolic fingerprinting and enterobacterial repetitive intergenic consensus sequence-PCR (ERIC-PCR). Microb. Ecol. 37: 129-139

Donegan KK, Palm CJ, Fieland VJ, Porteous LA, Ganio LM, Schaller DL, Bucao LQ, Seidler RJ (1995) Changes in levels, species and DNA fingerprints of soil microorganisms associated with cotton expressing the Bacillus thuringiensis var. kurstaki endotoxin. Appl. Soil Ecol. 2: 111-124

Dunfield KE, Germida JJ (2001) Diversity of bacterial communities in the rhizosphere and root interior of field-grown genetically modified Brassica napus. FEMS Microbiol. Ecol. 38: $1-9$

Dunfield KE, Germida JJ (2003) Seasonal changes in the rhizosphere microbial communities associated with field-grown genetically modified canola (Brassica napus). Appl. Environ. Microbiol. 69: 7310-7318

Einspanier R, Klotz A, Kraft J, Aulrich K, Poser R, Schwägele F, Jahreis G, Flachowsky G (2001) The fate of forage plant DNA in farm animals: a collaborative case-study investigating cattle and chicken fed recombinant plant material. Eur. Food Res. Technol. 212: 129-134

Falchini L, Naumova N, Kuikman PJ, Bloem J, Nannipieri P (2002) $\mathrm{CO}_{2}$ evolution and denaturing gradient gel electrophoresis profiles of bacterial communities in soil following addition of low molecular weight substrates to simulate root exudation. Soil Biol. Biochem. 36: 775-782

Fan T, Lane A, Pedler J, Crowley D, Higashi R (1997) Comprehensive analysis of organic ligands in whole root exudates using Nuclear Magnetic Resonance and Gas Chromatography Mass Spectrometry. Anal. Biochem. 251: 57-68

Figurski D, Helinski DR (1979) Replication of an origin containing derivative of plasmid RK2 dependent on a plasmid function provided in trans. PNAS 76: 1648-1652

Fisher MM, Triplett EW (1999) Automated approach for ribosomal intergenic spacer analysis of microbial diversity and its application to freshwater bacterial communities. Appl. Environ. Microbiol. 65: 4630-4636

Gallori E, Bazzicalupo M, Dal Canto L, Nannipieri P, Vettori C, Stotzky G (1994) Transformation of Bacillus subtilis by DNA bound on clay in non-sterile soil. FEMS Microbiol. Ecol. 15: 119-126

Gancedo MC, Luth BS (1986) HPLC analysis of organic acids and sugars in tomato juice. J. Food Science. 51: 571-573

Gomes NCM, Heuer H, Schönfeld J, Costa R, MendonçaHagler L, Smalla K (2001) Bacterial diversity of the rhizosphere of maize (Zea mays) grown in tropical soil studied by temperature gradient gel electrophoresis. Plant Soil 232: 167180

Gries D, Brunn S, Crowley D, Parker D (1995) Phytosiderophore release in relation to micronutrient metal deficiencies in barley. Plant Soil 172: 299-308

Gyamfi S, Pfeifer U, Stierschneider M, Sessitsch A (2002) Effects of transgenic gluphosinate-tolerant oilseed rape (Brassica napus) and the associated herbicide application on eubacterial and Pseudomonas communities in the rhizosphere. FEMS Microbiol. Ecol. 41: 181-190

Hammer Ø, Harper DAT, Ryan PD (2001) PAST: Paleontological Statistics Software Package for Education and Data Analysis. Palaeontologia Electronica 4: 1-9

Heuer H, Kroppenstedt RM, Lottmann J, Berg G, Smalla K (2002) Effects of T4 lysozyme release from transgenic potato roots on bacterial rhizosphere communities are negligible relative to natural factors. Appl. Environ. Microbiol. 68: 13251335

Hinsinger P, Gobran GR, Gregory PJ, Wenzel WW (2005) Rhizosphere geometry and heterogeneity arising from rootmediated physical and chemical processes. New Phytologist. 168: 293-303

Jackman LM, Sternhell S (1969) Applications of Nuclear Magnetic Resonance Spectroscopy in Organic Chemistry, 2nd edn. Pergamon Press, UK, pp 207-214

Kay E, Vogel TM, Bertolla F, Nalin R, Simonet P (2002) In situ transfer of antibiotic resistance genes from transgenic (transplastomic) tobacco plants to bacteria. Appl. Environ. Microbiol. 68: 3345-3351

Kent AD, Triplett EW (2002) Microbial communities and their interactions in soil and rhizosphere ecosystems. Ann. Rev. Microbiol. 56: 211-36

Khanna M, Stotzky G (1992) Transformation of Bacillus subtilis by DNA bound on montmorillonite and effect of DNase on the availability of bound DNA. Appl. Environ. Microbiol. 58: 1930-1939

Kok RG, Young DM, Ornston LN (1999) Phenotypic expression of PCR-generated random mutations in a Pseudomonas putida gene after its introduction into an Acinetobacter chromosome by natural transformation. Appl. Environ. Microbiol. 65: $1675-1780$

Lynch JM, Whipps JM (1990) Substrate flow in the rhizosphere. Plant Soil 129: 1-10

Magurran AE (1988) Ecological diversity and its measurement. Cambridge University Press, UK 


\section{Brusetti et al.}

Mansouri H, Petit A, Oger P, Dessaux Y (2002) Engineered rhizosphere: the trophic bias generated by opine-producing plants is independent of the opine type, the soil origin, and the plant species. Appl. Environ. Microbiol. 68: 2562-2566

McBee GG, Manes NO (1983) Determination of sucrose, glucose and fructose in plant tissue by HPLC. J. Chrom. 264: $474-478$

Milling A, Smalla K, Maidl FX, Schloter M, Munch JC (2004) Effects of transgenic potatoes with an altered starch composition on the diversity of soil and rhizosphere bacteria and fungi. Plant Soil 266: 23-39

Nielsen KM, Ray JL, Van Elsas JD (2004) Natural transformation in soil: microcosm studies. In Molecular Microbial Ecology Manual, 2nd edn, Kluwer Academic Publishers, The Netherlands, pp 1-12

Oger P, Petit A, Dessaux Y (1997) Genetically engineered plants producing opines alter their biological environment. Nature Biotech. 15: 369-372

Oger P, Mansouri H, Dessaux Y (2000) Effect of crop rotation and soil cover on alteration of the soil microflora generated by the culture of transgenic plants producing opines. Mol. Ecol. 9: $881-890$

Paget E, Monrozier LJ, Simonet P (1992) Adsorption of DNA on clay minerals: protection against DNase I and influence on gene transfer. FEMS Microbiol. Lett. 97: 31-40

Pal KK, Tilak KVBR, Saxena AK, Dey R, Singh CS (2001) Suppression of maize root diseases caused by Macrophomina phaseolina, Fusarium moniliforme and Fusarium graminearum by plant growth promoting rhizobacteria. Microbiol. Res. 156: 209-223

Persello-Cartieaux F, Nussaume L, Robaglia C (2003) Tales from the underground: molecular plant-rhizobacteria interactions. Plant Cell Environ. 26: 189-199

Pietramellara G, Dal Canto L, Vettori C, Gallori E, Nannipieri P (1997) Effects of air-drying and wetting cycles on the transforming ability of DNA bound on clay minerals. Soil Biol. Biochem. 29: 55-61
Savka MA, Farrand SK (1997) Modification of rhizobacterial populations by engineering bacterium utilisation of a novel plant produced resource. Nature Biotech. 15: 363-368

Sessitsch A, Kan F-Y, Pfeifer U (2003) Diversity and community structure of culturable Bacillus spp. populations in the rhizospheres of transgenic potatoes expressing the lytic peptide cecropin B. Appl. Soil Ecol. 22: 149-158

Siciliano SD, Germida JJ (1999) Taxonomic diversity of bacteria associated with the roots of field-grown transgenic Brassica napus cv. Quest, compared to the non-transgenic B. napus cv. Excel and B. rapa cv. Parkland. FEMS Microbiol. Ecol. 29: 263-272

Smalla K, Wieland G, Buchner A, Zock A, Parzy J, Kaiser S, Roskot N, Heuer H, Berg G (2001) Bulk and rhizosphere soil bacterial communities studied by denaturing gradient gel electrophoresis: plant-dependent enrichment and seasonal shifts revealed. Appl. Environ. Microbiol. 67: 4742-4751

Smit E, Leeflang P, Gommans S, van den Broek J, van Mil S, Wernars K (2001) Diversity and seasonal fluctuations of the dominant members of the bacterial soil community in a wheat field as determined by cultivation and molecular methods. Appl. Environ. Microbiol. 67: 2284-2291

Tepfer D, Garcia-Gonzaleset R, Mansouri H, Seruga M, Message B, Leach F, Curkovic Perica M (2003) Homologydependent DNA transfer from plants to a soil bacterium under laboratory conditions: implications in evolutions and horizontal gene transfer. Trans. Res. 12: 425-437

Vaneechoutte M, Young DM, Ornston LN, De Baere T, Nemec A, Van Der Reijden T, Carr E, Tjernberg I, Dijkshoorn L (2006) Naturally transformable Acinetobacter sp. strain ADP1 belongs to the newly described species Acinetobacter baylyi. Appl. Environ. Microbiol. 72: 932-936

Widmer F, Seidler RJ, Donegan KK, Reed GL (1997) Quantification of transgenic marker gene persistence in the field. Mol. Ecol. 6: 1-7

Wiren N, von Romheld V, Shioiri T, Marschner H (1995) Competition between micro-organism and roots of barley and sorghum for iron accumulated in the root apoplasm. New Phytol. 130: 511-521 